\title{
Two new species of Corydoras Lacépède, 1803 (Siluriformes: Callichthyidae) from the rio Madeira basin, Brazil
}

\author{
Luiz Fernando Caserta Tencatt ${ }^{1}$ and Willian Massaharu Ohara ${ }^{2}$
}

Two new species of Corydoras are described from the rio Madeira basin, Brazil. The intermediate long-snouted new species can be distinguished from its congeners by presenting the following combination of features: posterior margin of dorsalfin spine with laminar serrations directed towards the origin of the spine; presence of two longitudinal black stripes on flanks; anterior portion of dorsal fin with sparse black chromatophores, not forming any conspicuous pattern; absence of a conspicuous black marbled coloration pattern on head; black spots on caudal fin, some spots arranged, forming transversal bars; and brownish dorsal-fin spine. The short-snouted new species can be distinguished from its congeners by the following combination of features: short mesethmoid; posterior laminar expansion of infraorbital 2 very reduced, not in contact with compound pterotic; two or three longitudinal black stripes on flanks; absence of an oblique or vertical black blotch across the eye; anterior portion of dorsal fin with sparse black chromatophores, not forming any conspicuous pattern; and ventral surface of trunk naked or covered by sparse platelets.

Duas espécies novas de Corydoras são descritas da bacia do rio Madeira, Brasil. A espécie nova de focinho longo intermediário pode ser distinguida de suas congêneres por apresentar a seguinte combinação de características: margem posterior do espinho da nadadeira dorsal com serrilhas laminares direcionadas para origem do espinho; presença de duas faixas pretas longitudinais nos flancos; porção anterior da nadadeira dorsal com cromatóforos pretos esparsos, sem formar nenhum padrão conspícuo; ausência de um padrão de coloração marmoreado de preto conspícuo na cabeça; manchas pretas na nadadeira caudal, algumas delas alinhadas, formando barras transversais; e espinho dorsal amarronzado. A espécie nova de focinho curto pode ser distinguida de suas congêneres por apresentar a seguinte combinação de características: mesetmóide curto; expansão laminar posterior do infraorbital 2 muito reduzida, sem contato com o pterótico composto; duas ou três faixas pretas longitudinais nos flancos; ausência de uma mancha preta oblíqua ou vertical através do olho; porção anterior da nadadeira dorsal com cromatóforos pretos esparsos, sem formar nenhum padrão conspícuo; e superfície ventral do tronco nua ou coberta por plaquetas esparsas.

Keywords: Amazon, Corydoradinae, Mato Grosso, rio Aripuanã, Taxonomy.

\section{Introduction}

Corydoras Lacépède, 1803 is the most species-rich genus of Siluriformes, comprising approximately 170 valid species (Reis, 2003; Eschmeyer, 2015). The genus is widely distributed in cis-andean South America and the largest diversity is found in the Amazon basin, where more than the half of the known species occurs (see Eschmeyer, 2015). The species inhabit many different environments, from lakes and streams to large rivers. Typically found in shallow depths or close to the margins, Corydoras are often associated with sandy or muddy substrates.

Efforts to understand the taxonomy and systematics of Corydoras have included Ellis (1913), Gosline (1940), Nijssen (1970), Nijssen \& Isbrücker (1980), Britto (2003) and Alexandrou et al. (2011). Multiple studies have noted apparent cases of convergence of color pattern in Corydoras. Nijssen \& Isbrücker (1980) were the first to implicitly recognize a convergent color pattern by placing $C$. arcuatus Elwin, 1939 and C. narcissus Nijssen \& Isbrücker, 1980, two species with almost equal color pattern, into two different morphological groups, and noting that $C$. narcissus is more similar to C. acutus Cope, 1872 than to C. arcuatus. Britto et al. (2009) later described a third species with very similar color pattern to C. arcuatus and C. narcissus and showed that all three species belong to distinct clades. Based on phylogenetic analyses, Britto (2003) noted another case of apparent color convergence involving Corydoras nattereri Steindachner, 1876 in the Corydoras clade and C. prionotos Nijssen \& Isbrücker, 1980 in the Scleromystax clade.

\footnotetext{
${ }^{1}$ Universidade Estadual de Maringá, Programa de Pós-Graduação em Ecologia de Ambientes Aquáticos Continentais, Av. Colombo, 5790, 87020-900 Maringá, PR, Brazil. luiztencatt@hotmail.com (corresponding author)

${ }^{2}$ Museu de Zoologia da Universidade de São Paulo, Caixa Postal 42494, 04299-970 São Paulo, SP, Brazil. willianmohara@gmail.com
} 
Alexandrou et al. (2011) study of community structure in Corydoradinae was the first paper to explicitly hypothesize an adaptive basis for the convergence of color patterns in Corydoras. The study was based on a molecular phylogenetic analysis that established nine well-defined clades - each with characteristic snout morphology. The authors noted multiple cases of apparent convergence of color pattern within syntopic representatives of these clades, and provided evidence to support a hypothesis of Müllerian co-mimicry.

With recent survey efforts undertaken by the project "Monitoramento e Conservação da Ictiofauna do rio Madeira" (Assessment and conservation of the ichthyofauna of the rio Madeira) from 2009 to 2013. Britto (2013) documented 14 species of Corydoras from the Brazilian territory of the rio Madeira basin (but mentioned the occurrence of as many as twenty species). Here we report a new case of convergent color pattern in Corydoras. During a recent field expedition in the rio Aripuanã and its tributaries in the rio Madeira basin, two new species with similar color pattern but showing divergent snout morphology were found. In this paper, we describe these two sympatric and syntopic species and demonstrate that although they have similar color pattern, they belong to clearly distinct morphological groups that correspond to different lineages sensu Alexandrou et al. (2011).

\section{Material and Methods}

Measurements were obtained through digital calipers to the nearest tenth of millimeter. Morphometric and meristic data were taken following Reis (1997), with modifications of Tencatt et al. (2013). Morphometrics are reported as percentages of standard length (SL) and head length (HL). Homology and terminology of barbels follows Britto \& Lima (2003). For our osteological analysis, some specimens were cleared and stained (c\&s) following the protocol of Taylor \& Van Dyke (1985). Osteological terminology was based on Reis (1998), except for the use of parietosupraoccipital instead of supraoccipital (Arratia \& Gayet, 1995), compound pterotic instead of pterotic-supracleithrum (Aquino \& Schaefer, 2002), and scapulocoracoid instead of coracoid (Lundberg, 1970). Nomenclature of latero-sensory canals and preopercular pores are according to Schaefer \& Aquino (2000) and Schaefer (1988), respectively. The supra-preopercle sensu Huysentruyt \& Adriaens (2005) will be treated here as a part of the hyomandibula according to Vera-Alcaraz (2013). Vertebral counts include only free centra, with the compound caudal centra (preural 1+ ural 1) counted as a single element. Terminology of snout external morphology follows Alexandrou et al. (2011). In the description and diagnosis, the dark longitudinal stripes were counted only when well defined, continuous and not fused to the blackened dorsal portion of the fish's body.

Comparative data of the following species were obtained through their original descriptions and/or high resolution photographs of type-specimens hosted in the Natural History
Museum, London: Corydoras acrensis Nijssen, 1972, C. axelrodi Rössel, 1962, C. baderi Geisler, 1969, C. boesemani Nijssen \& Isbrücker, 1967, C. evelynae Rössel, 1963, C. gomezi Castro, 1986, C. habrosus Weitzman, 1960, C. haraldschultzi Knaack, 1962, C. isbrueckeri Knaack, 2004, C. leopardus Myers, 1933, C. loxozonus Nijssen \& Isbrücker, 1983, C. noelkempffi Knaack, 2004, C. ornatus Nijssen \& Isbrücker, 1976, C. orphnopterus Weitzman \& Nijssen, 1970, C. pulcher Isbrücker \& Nijssen, 1973, C. robustus Nijssen \& Isbrücker, 1980, C. schwartzi Rössel, 1963, C. sipaliwini Hoedeman, 1965, C. spectabilis Knaack, 2000, C. surinamensis Nijssen, 1970 and C. urucu Britto, Wosiacki \& Montag, 2009. Photographs of other pertinent type specimens were available for examination via the All Catfish Species Inventory website (Morris et al., 2006).

In the description, numbers between brackets represent the total number of specimens with those counts. Numbers with an asterisk refer to the counts of the holotype. Institutional abbreviations are: AI, Asociación Ictiológica de La Plata, La Plata; ANSP, Academy of Natural Sciences of Drexel University, Philadelphia; BMNH, The Natural History Museum, London; INPA, Instituto Nacional de Pesquisas da Amazônia, Manaus; LBP, Laboratório de Biologia de Peixes da Universidade Estadual Paulista, Botucatu; MCP, Museu de Ciências e Tecnologia da Pontifícia Universidade Católica, Porto Alegre; MCZ, Museum of Comparative Zoology, Harvard University, Cambridge; MNRJ, Museu Nacional, Universidade Federal do Rio de Janeiro, Rio de Janeiro; MZUSP, Museu de Zoologia da Universidade de São Paulo, São Paulo; NRM, Naturhistoriska Riksmuseet, Stockholm; NUP, Coleção Ictiológica do Núcleo de Pesquisas em Limnologia, Ictiologia e Aquicultura da Universidade Estadual de Maringá, Maringá; ROM, Royal Ontario Museum, Toronto; ZUFMS-PIS, Coleção Zoológica de Referência da Universidade Federal de Mato Grosso do Sul, Campo Grande.

\section{Results}

\section{Corydoras brittoi, new species}

urn:1sid:zoobank.org:act:3F9B3430-8D4C-4180-9B821E70648E7BD1

(Figs. 1-2a,b, 3a,c, 4, Table 1)

Holotype. MNRJ 43316, $38.1 \mathrm{~mm}$ SL, Brazil, Mato Grosso State, Colniza Municipality, Guariba District, tributary to the rio Guariba, rio Aripuanã drainage, rio Madeira basin, 0906'47.4”S 60²5'14.1'W, 15 Jul 2013, W. M. Ohara, D. B. Hungria \& B. Barros.

Paratypes. All from Brazil, Mato Grosso State, Colniza Municipality, Guariba District, rio Aripuanã drainage, rio Madeira basin. NUP 17311, 2, 32.4-35.2 mm SL, rio Aripuanã, 09²1’00”S 59¹9’33”W, 16 Jul 2013, W. M. Ohara, D. B. Hungria \& B. Barros; ZUFMS-PIS 4063, 1, 
$38.1 \mathrm{~mm}$ SL, Igarapé Pica-Pau, a tributary to the rio Juma, 09²2'27.2”S 6002'59.9'W, 16 Jul 2013, W. M. Ohara, D. B. Hungria \& B. Barros. INPA 48032, 4, 34.7-36.7 mm SL; MCP 48747, 3, 34.5-39.0 mm SL; MNRJ 43573, 4, 32.7-36.8 mm SL; MZUSP 117334, 5, 35.4-37.5 mm SL; NUP 17312, 4, 34.8-37.4 mm SL; NUP 17313, 2 c\&s, 31.4-34.1 mm SL; same data as the holotype.

Diagnosis. Corydoras brittoi can be distinguished from all of its congeners, with exception of the species from 'lineage 8' sensu Alexandrou et al. (2011), by the presence of posterior margin of dorsal-fin spine with laminar serrations directed towards the origin of the spine (vs. serrations, when present, conical; directed towards dorsal-fin spine tip in the members of the remaining lineages). Corydoras brittoi can be distinguished from other members of 'lineage 8', with exception of $C$. bifasciatus Nijssen, 1972, C. pinheiroi Dinkelmeyer, 1995 and C. pulcher, by the presence of two longitudinal black stripes on flanks (vs. presence of a single arched black stripe on dorsal portion of flank in C. arcuatus; stripe, when well defined, located on midline of flank in
C. gomezi, C. incolicana Burgess, 1993, C. leopardus, C. orphnopterus, C. robineae Burgess, 1983 and C. robustus; three to four slender longitudinal black stripes on flanks in $C$. ornatus; presence of three to four longitudinal rows of black spots on flanks, which may be coalescent and form stripes in some specimens of $C$. haraldschultzi, $C$. isbrueckeri, C. noelkempffi and C. spectabilis; absence of stripes on flanks in remaining species). Corydoras brittoi can be distinguished from $C$. bifasciatus and $C$. pulcher by presenting anterior portion of dorsal fin with sparse black chromatophores, not forming any conspicuous pattern (vs. conspicuously blackened in C. bifasciatus; hyaline with conspicuous whitish yellow pigmentation in $C$. pulcher); from $C$. pinheiroi by the absence of a conspicuous black marbled coloration pattern on head (vs. presence). Additionally, Corydoras brittoi can also be distinguished from $C$. bifasciatus by the presence of black spots on caudal fin, some spots arranged, forming transversal bars ( $v s$. spots absent, covered by brown chromatophores); from $C$. pulcher by the presence of brownish dorsal-fin spine (vs. conspicuously whitish yellow).

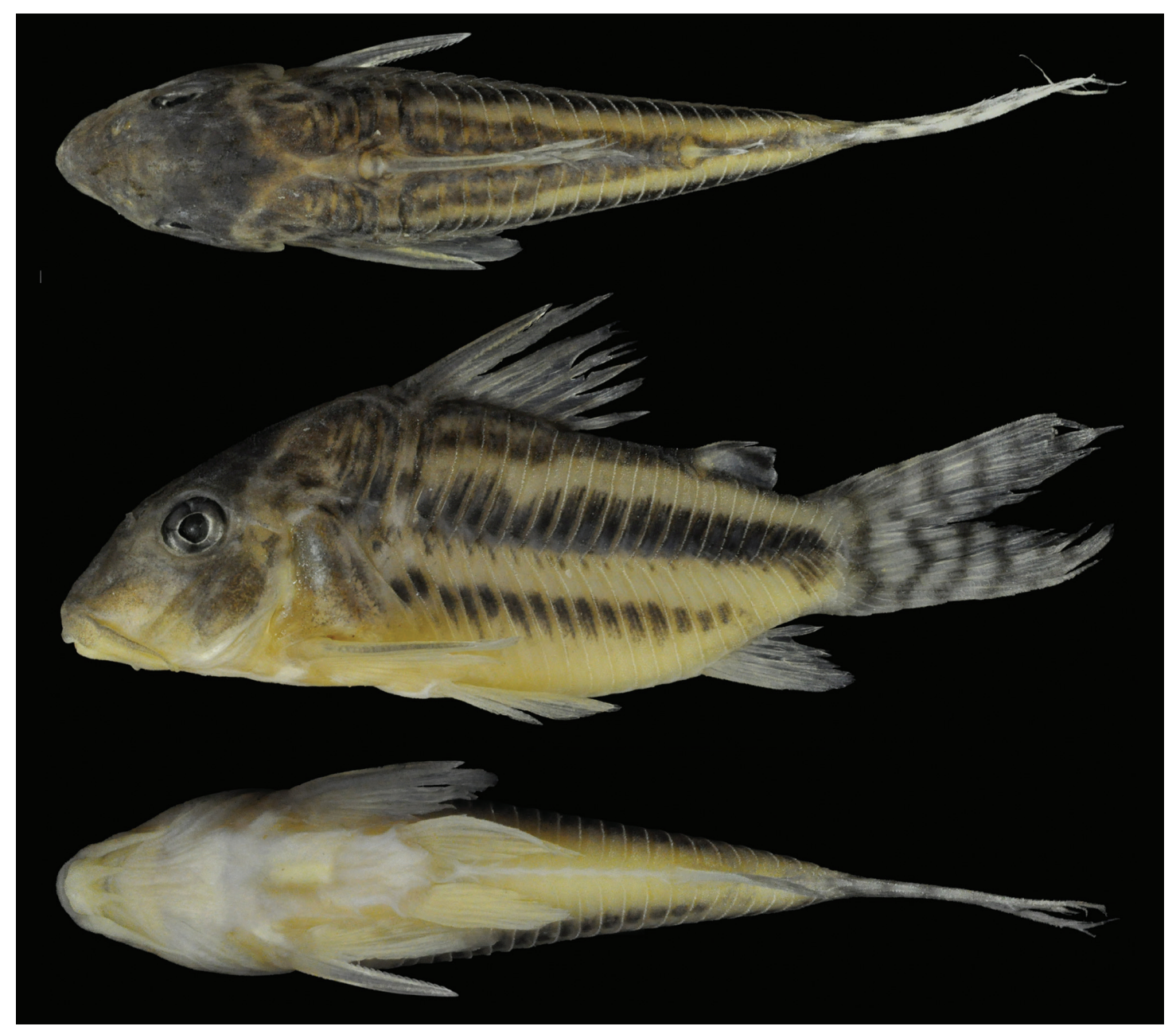

Fig. 1. Corydoras brittoi, holotype, MNRJ 43316, $38.1 \mathrm{~mm}$ SL, Brazil, Mato Grosso State, Colniza Municipality, Guariba District, tributary to the rio Guariba, rio Aripuanã drainage, rio Madeira basin, 0906'47.4”S 60²5'14.1'W. Dorsal (top), lateral (middle) and ventral (bottom) views. Photo by Celso Ikedo. 
Description. Morphometric data presented in Table 1. Head compressed with acutely convex dorsal profile; triangular in dorsal view. Snout pointed and straight. Head profile nearly straight from tip of snout to anterior nare; ascending nearly straight from this point to tip of posterior process of parietosupraoccipital. Profile slightly convex along dorsal-fin base. Postdorsal-fin body profile nearly straight to adipose-fin spine; concave from this point to caudal-fin base. Ventral profile of body slightly convex from isthmus to base of first anal-fin ray; concave from this point to caudal-fin base. Body acutely elliptical in cross section at pectoral girdle, gradually becoming more compressed toward caudal fin.

Eye rounded, located dorso-laterally on head; orbit delimited dorsally by lateral ethmoid, frontal and sphenotic, ventrally by infraorbitals. Anterior and posterior nares close to each other, only separated by flap of skin. Anterior naris tubular. Posterior naris relatively distant to anterodorsal margin of orbit, separated from it by distance equal to twice of naris diameter. Mouth small, subterminal, width nearly equal to bony orbit diameter. Maxillary barbel relatively large, almost reaching anteroventral limit of gill opening. Outer mental barbel slightly larger than maxillary barbel. Inner mental barbel fleshy, with base close to its counterpart. Small rounded papillae covering entire surface of all barbels, upper and lower lips, and isthmus.
Mesethmoid long; anterior tip well developed, larger than $50 \%$ of bone length (see Britto, 2003: 123, character 1 , state 0 ; fig. 1A); posterior portion conspicuously narrow and entirely covered by a thick layer of skin. Nasal slender, curved laterally, with very reduced laminar expansion on its inner margin; mesial border contacting only frontal. Frontal elongated, narrow, with width slightly smaller than half of entire length; anterior projection short, size smaller than nasal length. Frontal fontanel large, oblong; posterior tip extension slightly entering anterior margin of parietosupraoccipital. Parieto-supraoccipital wide, posterior process long and contacting nuchal plate; region of contact between posterior process and nuchal plate covered by thick layer of skin.

Two laminar infraorbitals with minute odontodes; infraorbital 1 large, ventral laminar expansion poorly developed; anterior portion with well-developed expansion (Fig. 2a); infraorbital 2 small, slender; with posterior laminar expansion well developed; posteroventral margin contacting posterodorsal ridge of hyomandibula, dorsal tip contacting sphenotic and compound pterotic (Fig. 2b). Posterodorsal ridge of hyomandibula close to its articulation with opercle oblong; exposed, conspicuously slender; dorsal ridge of hyomandibula between compound pterotic and opercle covered by thick layer of skin; exposed

Table 1. Morphometric data for Corydoras brittoi and Corydoras pavanelliae. $\mathrm{N}=$ number of measured specimens and SD $=$ standard deviation.

\begin{tabular}{|c|c|c|c|c|c|c|c|c|}
\hline & \multicolumn{4}{|c|}{ Corydoras brittoi } & \multicolumn{4}{|c|}{ Corydoras pavanelliae } \\
\hline & $\mathrm{N}$ & Holotype & Low-High & Mean \pm SD & $\mathrm{N}$ & Holotype & Low-High & Mean \pm SD \\
\hline Standard length (mm) & 20 & 38.1 & $31.4-39.0$ & $36.1 .5 \pm 1.8$ & 20 & 45.1 & $23.3-45.1$ & $26.6 \pm 4.8$ \\
\hline \multicolumn{9}{|c|}{ Percents of standard length } \\
\hline Depth of body & 20 & 38.6 & $34.7-40.5$ & $38.7 \pm 1.2$ & 20 & 43.2 & $35.8-43.2$ & $38.7 \pm 1.6$ \\
\hline Predorsal distance & 20 & 51.2 & $49.5-53.3$ & $51.1 \pm 0.8$ & 20 & 54.5 & $48.6-54.5$ & $52.2 \pm 1.6$ \\
\hline Prepelvic distance & 20 & 48.8 & $47.8-51.1$ & $49.1 \pm 0.7$ & 20 & 50.1 & $45.8-51.4$ & $48.3 \pm 1.5$ \\
\hline Preanal distance & 20 & 83.2 & $80.3-85.1$ & $82.1 \pm 1.2$ & 20 & 85.8 & $78.1-85.8$ & $81.3 \pm 1.8$ \\
\hline Preadipose distance & 20 & 84.3 & $83.8-86.5$ & $84.8 \pm 0.9$ & 20 & 88.2 & $83.5-88.7$ & $85.6 \pm 1.5$ \\
\hline Length of dorsal spine & 19 & 23.6 & $23.6-27.2$ & $25.3 \pm 1.2$ & 19 & 30.8 & $26.7-32.4$ & $30.3 \pm 1.4$ \\
\hline Length of pectoral spine & 20 & 24.9 & $24.2-27.2$ & $25.9 \pm 0.9$ & 20 & 31.7 & $28.7-33.8$ & $31.1 \pm 1.3$ \\
\hline Length of adipose-fin spine & 19 & 8.4 & $8.0-10.2$ & $9.0 \pm 0.6$ & 20 & 8.6 & 7.6-9.8 & $8.7 \pm 0.7$ \\
\hline Depth of caudal peduncle & 20 & 14.7 & $13.7-15.7$ & $14.9 \pm 0.5$ & 20 & 15.7 & $15.0-16.9$ & $15.8 \pm 0.6$ \\
\hline Length of dorsal-fin base & 20 & 19.4 & $18.6-21.6$ & $20.2 \pm 0.8$ & 20 & 19.3 & $16.7-19.5$ & $18.1 \pm 0.8$ \\
\hline Dorsal to adipose distance & 20 & 16.8 & $14.9-19.1$ & $16.7 \pm 1.3$ & 20 & 18.2 & $18.0-20.5$ & $19.3 \pm 0.8$ \\
\hline Maximum cleithral width & 20 & 23.1 & $22.9-25.2$ & $24.0 \pm 0.6$ & 20 & 29.3 & $26.5-29.3$ & $27.7 \pm 0.8$ \\
\hline Head length & 20 & 44.4 & $42.6-49.0$ & $45.0 \pm 1.4$ & 20 & 47.7 & $44.2-48.6$ & $46.6 \pm 1.3$ \\
\hline Length of maxillary barbel & 20 & 17.3 & $12.1-19.2$ & $16.3 \pm 1.5$ & 20 & 15.1 & $9.7-15.1$ & $12.3 \pm 1.7$ \\
\hline \multicolumn{9}{|c|}{ Percents of head length } \\
\hline Head depth & 20 & 79.2 & $71.9-84.3$ & $81.0 \pm 3.1$ & 20 & 84.7 & $73.3-84.7$ & $79.1 \pm 2.9$ \\
\hline Least interorbital distance & 20 & 29.2 & $28.1-32.3$ & $31.0 \pm 1.2$ & 20 & 33.5 & $29.3-34.0$ & $31.4 \pm 1.3$ \\
\hline Horizontal orbit diameter & 20 & 22.8 & $20.9-24.3$ & $22.8 \pm 0.8$ & 20 & 21.4 & $21.4-27.4$ & $24.9 \pm 1.3$ \\
\hline Snout length & 20 & 33.2 & $35.9-43.4$ & $40.7 \pm 1.8$ & 20 & 37.7 & $32.7-37.8$ & $35.3 \pm 1.4$ \\
\hline Least internarial distance & 20 & 14.9 & $10.0-14.5$ & $12.6 \pm 1.1$ & 20 & 16.3 & $11.8-16.3$ & $14.2 \pm 1.1$ \\
\hline
\end{tabular}


areas bearing small odontodes. Interopercle covered by thin layer of skin, somewhat triangular, anterior projection well-developed. Preopercle slender, elongated, minute odontodes sparse on external surface. Opercle elongated dorso-ventrally, width smaller than half of its length; free margin convex, without serrations and covered by small odontodes. Anteroventral portion of cleithrum and posterolateral portion of scapulocoracoid exposed; minute odontodes sparse on exposed areas. Vertebral count 22 (2); ribs 7 (2), first pair conspicuously large; complex vertebra slender in shape. Neural and haemal spines with pointed distal tips.

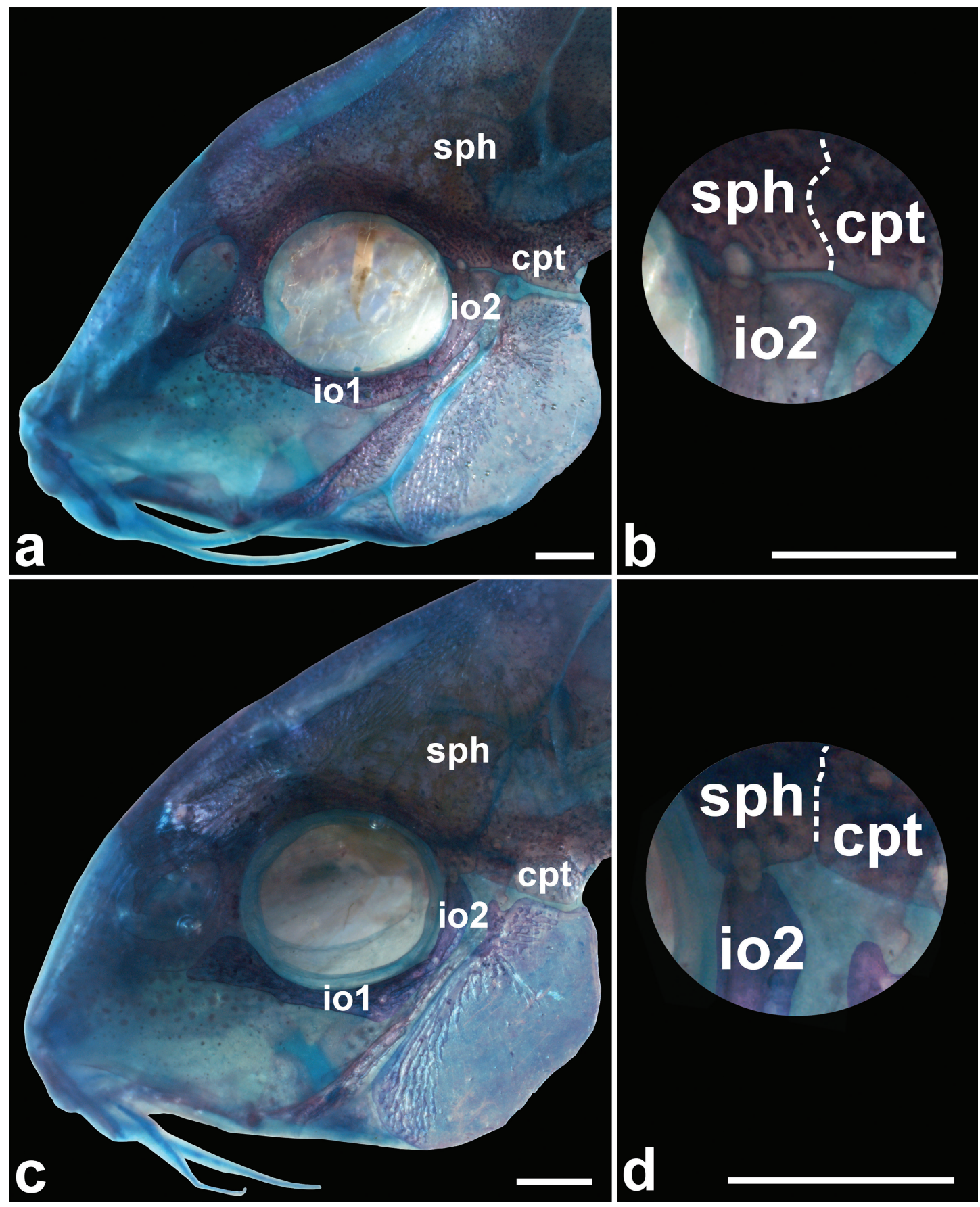

Fig. 2. Lateral view of the head of c\&s specimens of Corydoras brittoi, NUP 17313, $34.1 \mathrm{~mm}$ SL, showing the poorlydeveloped ventral expansion of the infraorbital 1 (a) and infraorbital 2 in contact with compound pterotic (b), and of Corydoras pavanelliae, NUP 17315, $25.4 \mathrm{~mm}$ SL, showing the poorly-developed ventral expansion of the infraorbital 1 (c) and infraorbital 2 not in contact with compound pterotic (d). The dotted lines in (b) and (d) represent the suture between sphenotic and compound pterotic bones. Abbreviations: io1: infraorbital 1, io2: infraorbital 2, sph: sphenotic, cpt: compound pterotic. Scale bar $=1.0 \mathrm{~mm}$. 
Four branchiostegal rays decreasing in size posteriorly. Hypobranchial 2 somewhat triangular, tip ossified and directed towards anterior portion, posterior margin cartilaginous; ossified portion well developed, about twice size of cartilaginous portion. Five ceratobranchials with expansions increasing posteriorly; ceratobranchial 1 with a very reduced process on anterior margin of mesial portion; ceratobranchial 3 notched on postero-lateral margin; ceratobranchial 5 toothed on postero-dorsal surface, 34 to 36 (2) teeth aligned in one row. Four epibranchials with similar size; epibranchial 2 slightly larger than others, with small pointed process on laminar expansion of posterior margin; epibranchial 3 with somewhat quadrangular uncinate process on laminar expansion of posterior margin. Two wide pharyngobranchials ( 3 and 4), pharyngobranchial 3 with a rippled laminar expansion on posterior margin. Upper tooth plate oval; 34 to 40 (2) teeth aligned in two rows on postero-ventral surface.

Lateral-line canal entering neurocranium through compound pterotic, splitting into two branches before entering sphenotic: pterotic branch with a single pore; preoperculomandibular branch conspicuously reduced, with a single pore opening close to postotic main canal. Sensory canal continuing through compound pterotic, entering sphenotic as temporal canal, which splits into two branches: one branch giving rise to infraorbital canal, other branch entering frontal through supraorbital canal, both with single pore. Supraorbital canal not branched, running through nasal bone. Epiphyseal pore opening at supraorbital main canal; slightly directed toward frontal fontanel region. Nasal canal with three openings, first on posterior edge, second on posterolateral portion and third on anterior edge. Infraorbital canal running through entire second infraorbital, extending to infraorbital 1 and opening into two pores. Preoperculomandibular branch giving rise to preoperculo-mandibular canal, which runs through entire preopercle with three openings, leading to pores 3, 4, and 5 , respectively.

Dorsal fin triangular, located just posterior to second dorsolateral body plate. Dorsal-fin rays II, 8 , posterior margin of dorsal-fin spine 11 to 14 moderately-developed serrations directed towards dorsal-fin spine origin; serrations absent proximally (Fig. 3a). Nuchal plate moderately developed; exposed, with minute odontodes; spinelet short; spine moderately developed, adpressed distal tip reaching to or slightly surpassing origin of last dorsal-fin branched ray; anterior margin with small odontodes. Pectoral fin triangular, its origin just posterior to gill opening. Pectoralfin rays I,8 (17), I,9* (3); posterior margin of pectoral-fin spine with 17 to 19 moderately-developed laminar serrations along its entire length; serrations directed towards pectoralfin spine origin (Fig. 3c). Pelvic fin oblong, located just below first ventrolateral body plate, and at vertical through first branched dorsal-fin ray. Pelvic-fin rays i,5. Adipose fin roughly triangular, separated from base of last dorsalfin ray by generally six dorsolateral body plates. Anal fin triangular, located just posterior to $13^{\text {th }}$ ventrolateral body plates, and at vertical through anterior margin of adiposefin spine. Anal-fin rays ii,6. Caudal-fin rays i,12,i, generally five dorsal and ventral procurrent rays; bilobed; dorsal lobe generally slightly larger than ventral lobe.

Three laterosensory canals on trunk; first ossicle tubular, second ossicle laminar, third lateral-line canal encased in third dorsolateral body plate. Body plates with minute odontodes scattered over exposed area, a conspicuous line of odontodes confined on posterior margins; dorsolateral body plates 22 (4), 23* (14), 24 (2); ventrolateral body plates 20* (12), 21 (8); dorsolateral body plates along dorsal-fin base $6^{*}(18), 7$ (2); dorsolateral body plates between adipose and caudal fins $6(7), 7^{*}(12), 8$ (1); preadipose platelets 2 (1), 3* (18), 4 (1); small platelets covering base of caudalfin rays; small platelets disposed dorsally and ventrally between junctions of lateral plates on posterior portion of caudal peduncle. Anterior margin of orbit, above lateral ethmoid, dorsal surface of snout, nasal capsule region, and upper lip covered by platelets bearing odontodes. Ventral surface of trunk covered by sparse irregular platelets bearing odontodes.

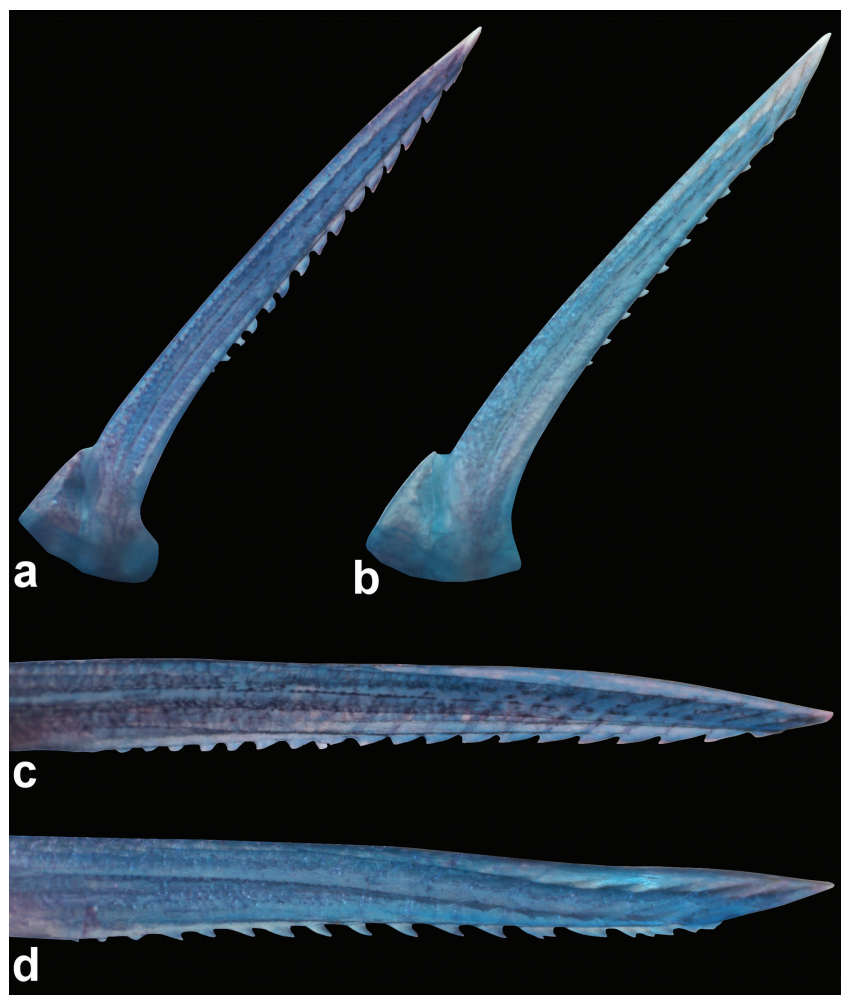

Fig. 3. Dorsal- and pectoral-fin spines of (a, c) Corydoras brittoi, NUP 17313, $34.1 \mathrm{~mm}$ SL, showing serrations directed towards the origins of the spines on posterior margins of the (a) dorsal-fin spine (8.6 mm long) and of the (c) right pectoral-fin spine (8.9 mm long), and of (b, d) Corydoras pavanelliae, NUP 17315, $26.8 \mathrm{~mm} \mathrm{SL}$, showing serrations directed towards the tips of the spines on posterior margins of the (b) dorsal-fin spine $(7.9 \mathrm{~mm}$ long) and of the (d) right spine (7.6 $\mathrm{mm}$ long). 
Color in alcohol. Overall color of body in Fig. 1. Ground color of body pale yellow, with top of head and snout dark brown; interorbital region with more intense brown pigmentation; nuchal plate and border of process of parietosupraoccipital contacting first dorsolateral body plate light yellow. Medial portion of opercle and cleithrum, posterior portion of compound pterotic, preopercle, infraorbitals 1 and 2, upper lip, maxillary barbel and anterior portion of outer mental barbel covered by brownish chromatophores. First, second and third dorsolateral body plates almost entirely blackened. Dorsal portion of body irregularly black pigmented, forming diffuse longitudinal black stripe; black stripe larger on dorsal-fin base region becoming narrow towards caudal peduncle. Body with two conspicuous longitudinal black stripes. Midventral half of dorsolateral body plates blackened, forming broad longitudinal stripe along flank. Medial portion of ventrolateral body plates anterior to anal-fin last branched ray region blackened, forming slender longitudinal black stripe along flank. Dorsal fin covered by sparse black chromatophores; chromatophores slightly more concentrated on region of first and second dorsal-fin rays, including membranes; chromatophores generally absent close to dorsal-fin base; dorsal-fin spine brownish. Pectoral-fin rays with sparse black chromatophores; pectoral-fin spine brownish. Pelvic fin hyaline. Adipose fin covered by black chromatophores on its medial portion; black pigmentation more intense, forming an irregular conspicuous elongated black blotch in some specimens; adipose-fin spine dorsal half blackened. Caudal-fin base blackened; caudal-fin lobes with black spots; some spots arranged in one to four transversal black bars.

Color in life. Very similar to preserved specimens but with ground color of body whitish yellow. Region of contact between process of parieto-supraoccipital and nuchal plate bright yellow. Body covered by greenish yellow iridescent coloration, more concentrated on lower half of opercle, infraorbitals, cleithrum and on region of two longitudinal lateral stripes (Fig. 4).

Sexual dimorphism. Except for the presence of lanceolate genital papilla in males, which occurs in all Corydoradinae (see Nijssen \& Isbrücker, 1980; Britto, 2003), no other sexually dimorphic feature was observed.

Distribution. The new species is known from the rio Aripuanã basin, Mato Grosso State (Fig. 5).

Ecological notes. The type locality of Corydoras brittoi is located at 110 meters above sea level, and is a small clear water stream, with 2-3 m width and 0.5-2 m depth, with preserved riparian vegetation, swift water current, and bottom composed mainly of sand and dead leaves. Specimens of $C$. brittoi were observed at night during capture at shallow portions of the stream in small groups (5-15 individuals), and sometimes associated with a other new species described below.

Etymology. Corydoras brittoi is named in honor of Marcelo Ribeiro de Britto, a dear friend and mentor, for his extensive contributions to the taxonomy and systematics of the Corydoradinae. A genitive.

Conservation status. Corydoras brittoi is so far known only from the type-locality and its conservation status is uncertain based on the limited knowledge of its geographic distribution. However, considering that important threats to the species were not detected in the area, and that it occurs in a protected area (Reserva Extrativista Guariba Roosevelt), Corydoras brittoi would be classified as Least Concern (LC) according to the International Union for Conservation of Nature (IUCN) categories and criteria (IUCN Standards and Petitions Subcommittee, 2014).

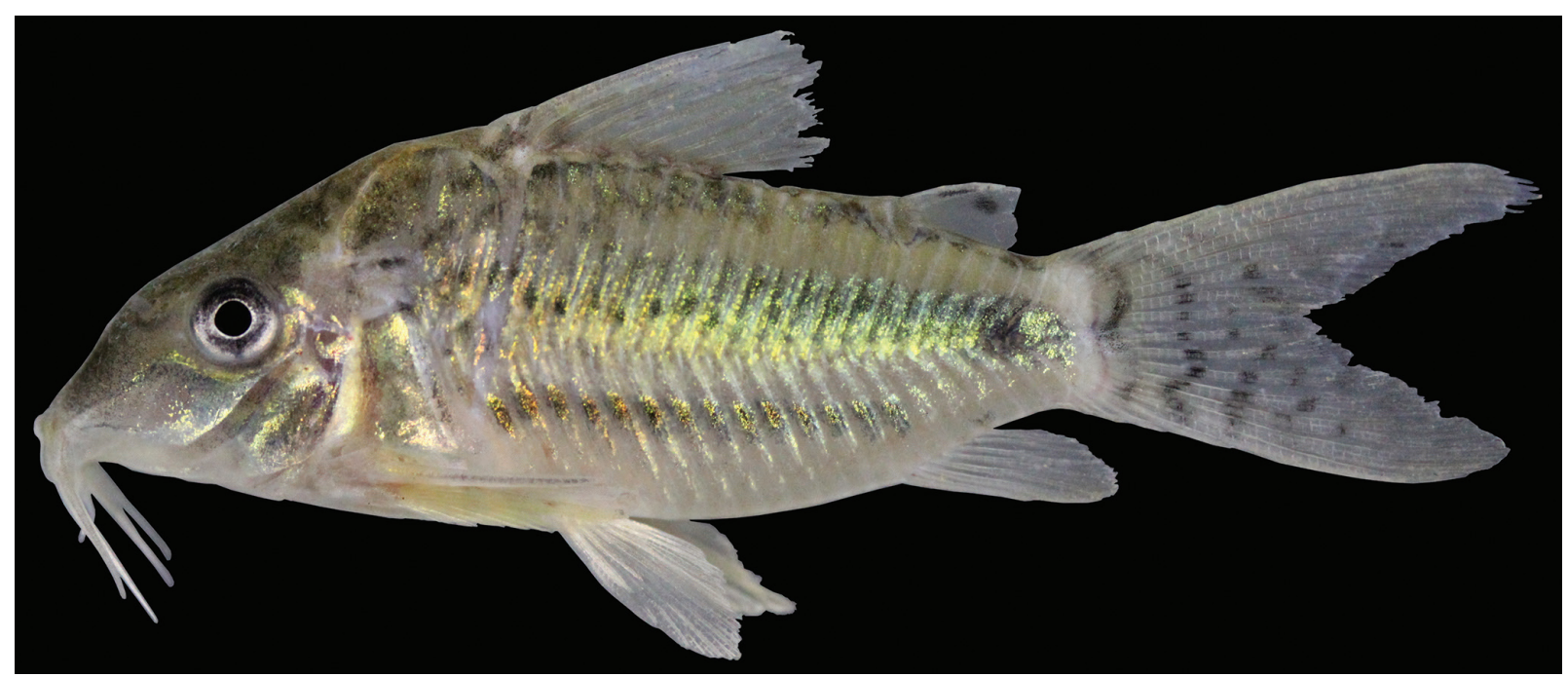

Fig. 4. Specimen of Corydoras brittoi photographed in life, showing the iridescent greenish yellow coloration all over the body. 


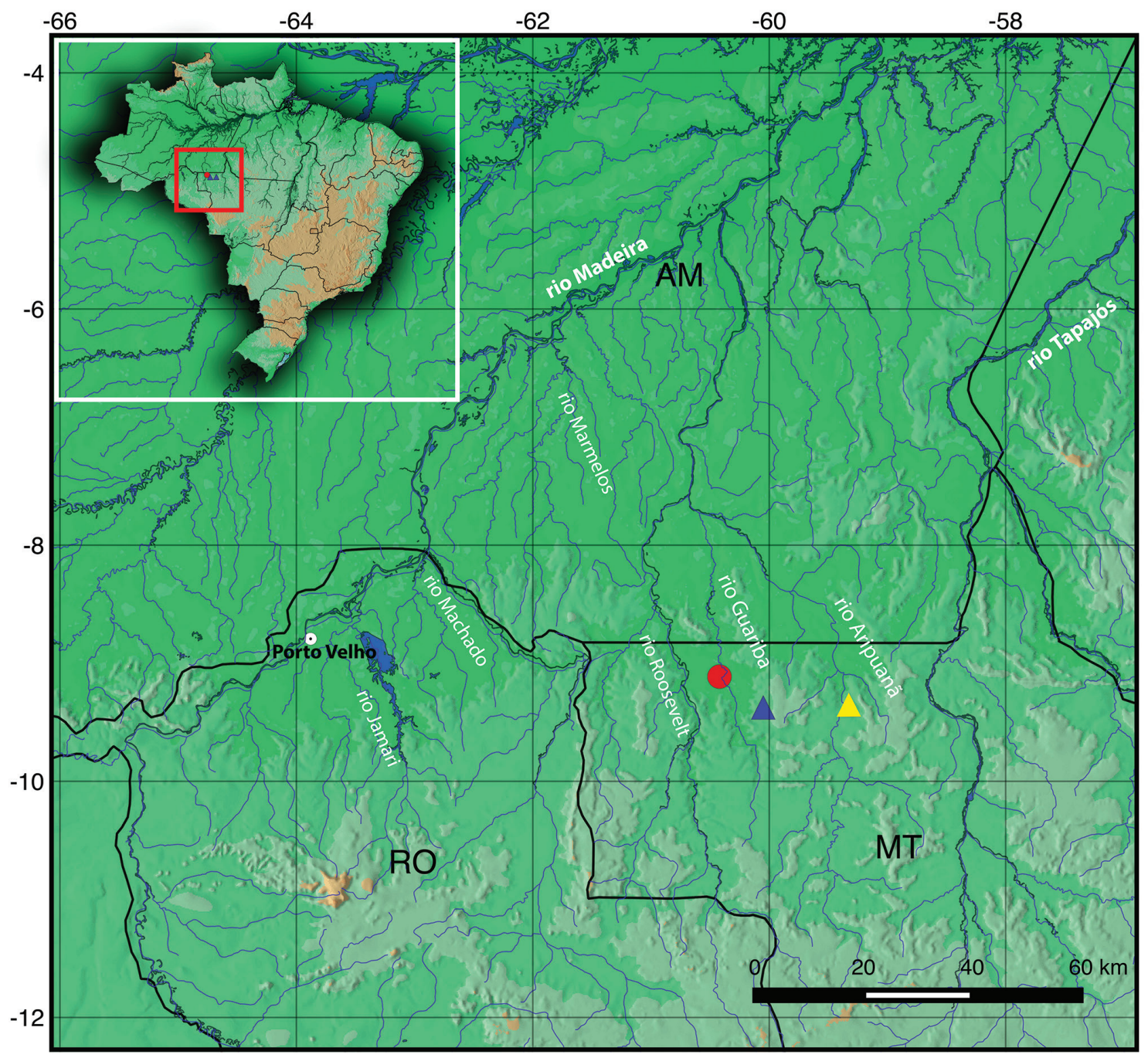

Fig. 5. Map showing the type-locality (red circle) of Corydoras brittoi and Corydoras pavanelliae, a tributary to the rio Guariba, Mato Grosso. The blue triangle represents the Igarapé Pica-Pau, also a tributary to the rio Guariba, and the yellow triangle represents the rio Aripuanã, both representing additional records of C. brittoi.

\section{Corydoras pavanelliae, new species}

urn:1sid:zoobank.org:act:3DDD5672-0B60-49C4-8720E7DA1013CDE3

(Figs. 2c,d, 3b,d, 6, Table 1)

Holotype. MNRJ 43317, $45.1 \mathrm{~mm}$ SL, Brazil, Mato Grosso State, Colniza Municipality, Guariba District, tributary to the rio Guariba, rio Aripuanã drainage, rio Madeira basin, 0906'47.4”S 60²5'14.1”W, 15 Jul 2013, W. M. Ohara, D. B. Hungria \& B. Barros.

Paratypes. INPA 48033, 5, 22.5-23.2 mm SL; MCP 48748, 5, 19.0-23.5 mm SL; MZUSP 117335, 10, 21.8-25.4 mm SL; NUP 17314, 17, 20.8-30.7 mm SL; NUP 17315, 3 c\&s, 24.726.8 mm SL; ZUFMS-PIS 4064, 8, 20.0-22.9 mm SL; same data as the holotype.
Diagnosis. Corydoras pavanelliae can be distinguished from its congeners, with exception of species from lineages '4', '5', '6', '7' and '9' sensu Alexandrou et al. (2011) by the presence of a short mesethmoid, with anterior portion smaller than $50 \%$ of the bone length (vs. long, equal or larger than $50 \%$ of the bone length). Corydoras pavanelliae can be distinguished from species of lineages ' 4 ', ' 5 ' and '7' sensu Alexandrou et al. (2011) by the absence of contact between infraorbital 2 and compound pterotic (Figs. 2c,d) (vs. presence (see Tencatt \& Pavanelli (2015: 291, fig. 3))). Corydoras pavanelliae can be distinguished from lineages ' 6 ' and '9' sensu Alexandrou et al. (2011), with the exception of C. axelrodi, C. evelynae, C. loxozonus, C. parallelus Burgess, 1993, C. schwartzi and C. surinamensis, by the presence of two or three longitudinal black stripes on flanks (vs. a longitudinal black stripe along midline of flank in C. acrensis, C. baderi, C. boesemani, C. bondi Gosline, 1940, C. coppenamensis Nijssen, 1970, C. habrosus, C. julii 
Steindachner, 1906, C. nattereri, C. sipaliwini, C. trilineatus Cope, 1872; a longitudinal series of large black blotches along midline of flank in $C$. diphyes Axenrot \& Kullander, 2003, C. ehrhardti Steindachner, 1910, C. flaveolus Ihering, 1911, C. longipinnis Knaack, 2007, C. paleatus (Jenyns, 1842), C. reynoldsi Myers \& Weitzman, 1960 and $C$. tukano Britto \& Lima, 2003; flanks densely covered by small rounded black spots, which can be diffuse or absent in some specimens, in C. albolineatus Knaack, 2004 and C. potaroensis Myers, 1927; a single oblique black stripe from dorsal-fin base region descending to base of caudal peduncle in C. melini Lönnberg \& Rendahl, 1930; four to six longitudinal rows of black spots on flanks, which may be coalescent and form stripes in some specimens of C. sterbai
Knaack, 1962; presence of a single arched black stripe on dorsal portion of flank in C. urucu; absence of stripes on flanks in remaining species). Corydoras pavanelliae can be distinguished from C. axelrodi, C. evelynae, C. loxozonus, C. parallelus, C. schwartzi and C. surinamensis by the absence of an oblique or vertical black blotch across the eye (vs. presence); from C. axelrodi, C. evelynae, C. loxozonus, $C$. parallelus and $C$. surinamensis by presenting anterior portion of dorsal fin with sparse black chromatophores, not forming any conspicuous pattern (vs. entirely or almost entirely conspicuously blackened); from C. evelynae and C. schwartzi by having ventral surface of trunk naked or covered by sparse platelets ( $v s$. densely covered by coalescent platelets).

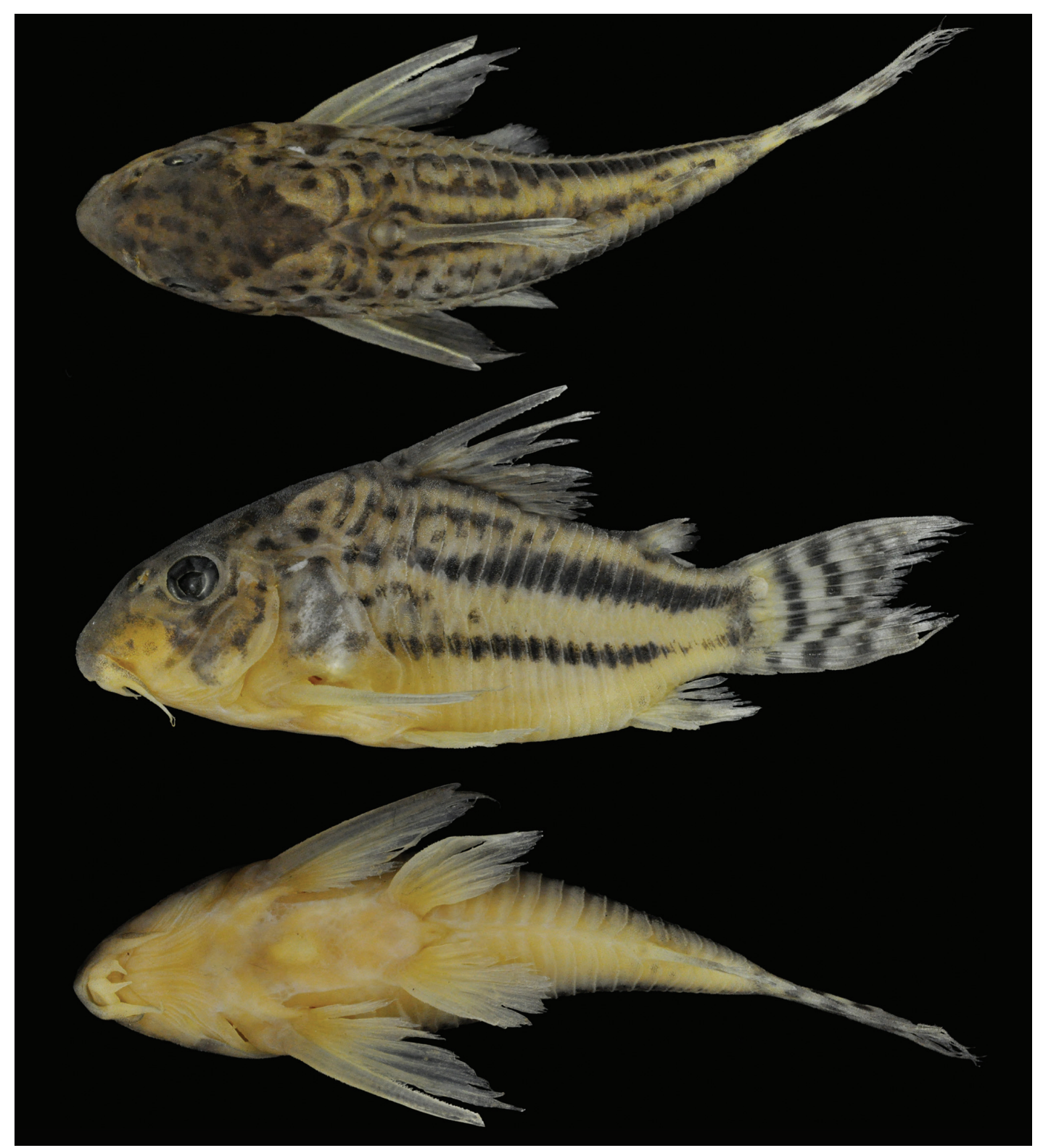

Fig. 6. Corydoras pavanelliae, holotype, MNRJ 43317, 45.1 mm SL, Brazil, Mato Grosso State, Colniza Municipality, Guariba District, tributary to the rio Guariba, rio Aripuanã drainage, rio Madeira basin, 0906'47.4”S 60²5'14.1”W. Dorsal (top), lateral (middle) and ventral (bottom) views. Photo by Celso Ikedo. 
Description. Morphometric data presented in Table 1. Head compressed with convex dorsal profile; triangular in dorsal view. Snout short and slightly pointed. Head profile convex from tip of snout to anterior nares; ascending nearly straight from this point to tip of posterior process of parieto-supraoccipital; region just anterior to nares slightly concave in some specimens. Profile slightly convex along dorsal-fin base. Postdorsal-fin body profile nearly straight to adipose-fin spine; concave from this point to caudal-fin base. Ventral profile of body slightly convex from isthmus to pelvic girdle. Profile nearly straight from pelvic girdle to base of first anal-fin ray; abruptly concave from this point to caudal-fin base. Body roughly elliptical in cross section at pectoral girdle, gradually becoming more compressed toward caudal fin.

Eye rounded, located dorso-laterally on head; orbit delimited dorsally by lateral ethmoid, frontal and sphenotic, ventrally by infraorbitals. Anterior and posterior nares close to each other, only separated by flap of skin. Anterior naris tubular. Posterior naris close to anterodorsal margin of orbit, separated from it by distance equal to naris diameter. Mouth small, subterminal, width nearly equal to bony orbit diameter. Maxillary barbel moderate in size, not reaching anteroventral limit of gill opening. Outer mental barbel slightly larger than maxillary barbel. Inner mental barbel fleshy, base slightly separated to its counterpart; insertion of barbel in middle of lower lip. Small rounded papillae covering entire surface of all barbels, upper and lower lips, and isthmus.

Mesethmoid short; anterior tip moderately developed, smaller than 50\% of bone length (see Britto, 2003: 123, character 1, state 1; fig. 1B); posterior portion relatively wide and entirely covered by thick layer of skin. Nasal slender, curved laterally, with inner margin laminar; mesial border contacting only frontal. Frontal elongated, narrow, with width slightly smaller than half of entire length; anterior projection short, size smaller than nasal length. Frontal fontanel large, oval; posterior tip extension slightly entering anterior margin of parieto-supraoccipital. Parietosupraoccipital wide, posterior process long and contacting nuchal plate; region of contact between posterior process and nuchal plate covered by thick layer of skin.

Two laminar infraorbitals with minute odontodes; infraorbital 1 large, ventral laminar expansion poorly developed; moderately developed in larger specimens (see Britto, 2003: 128, fig. 5B); anterior portion with well-developed expansion (Fig. 2c); infraorbital 2 small, slender; with posterior laminar expansion very reduced; posteroventral margin contacting posterodorsal ridge of hyomandibula, dorsal tip contacting only sphenotic (Fig. 2d). Posterodorsal ridge of hyomandibula close to its articulation with opercle oblong; slender, exposed and bearing small odontodes; dorsal ridge of hyomandibula between compound pterotic and opercle covered by thick layer of skin. Interopercle entirely covered by thick layer of skin, somewhat triangular, anterior projection well-developed. Preopercle slender, elongated, minute odontodes sparse on external surface. Opercle elongated dorso-ventrally, width smaller than half of its length; free margin smoothly convex, without serrations and covered by small odontodes. Anteroventral portion of cleithrum and posterolateral portion of scapulocoracoid exposed; minute odontodes sparse on exposed areas. Vertebral count 21 (3); ribs 6 (3), first pair conspicuously large; complex vertebra compact in shape. Neural and haemal spines with pointed distal tips.

Four branchiostegal rays decreasing in size posteriorly. Hypobranchial 2 somewhat triangular, tip ossified and directed towards anterior portion, posterior margin cartilaginous; ossified portion well developed, about twice size of cartilaginous portion. Five ceratobranchials with expansions increasing posteriorly; ceratobranchial 1 with small process on anterior margin of mesial portion; ceratobranchial 3 notched on postero-lateral margin; ceratobranchial 5 toothed on postero-dorsal surface, 33 to 39 (3) teeth aligned in one row. Four epibranchials with similar size; epibranchial 2 slightly larger than others, with small pointed process on laminar expansion of posterior margin; epibranchial 3 with curved mesially uncinate process on laminar expansion of posterior margin. Two wide pharyngobranchials (3 and 4), pharyngobranchial 3 with small triangular laminar expansion on posterior margin. Upper tooth plate oval; 41 to 43 (3) teeth aligned in two rows on postero-ventral surface.

Lateral-line canal entering neurocranium through compound pterotic, splitting into two branches before entering sphenotic: pterotic branch with a single pore; preoperculomandibular branch conspicuously reduced, with a single pore opening close to postotic main canal. Sensory canal continuing through compound pterotic, entering sphenotic as temporal canal, which splits into two branches: one branch giving rise to infraorbital canal, other branch entering frontal through supraorbital canal, both with a single pore. Supraorbital canal not branched, running through nasal bone. Epiphyseal pore opening at supraorbital main canal. Nasal canal with three openings, first on posterior edge, second on posterolateral portion and third on anterior edge. Infraorbital canal running through entire second infraorbital, extending to infraorbital 1 and opening into two pores. Preoperculomandibular branch giving rise to preoperculo-mandibular canal, which runs through entire preopercle with three openings, leading to pores 3,4 , and 5 , respectively.

Dorsal fin triangular, located just posterior to second dorsolateral body plate. Dorsal-fin rays II,8, posterior margin of dorsal-fin spine with nine to 12 reduced serrations directed towards tip of spine; serrations absent proximally (Fig. 3b). Nuchal plate moderately developed; exposed, with minute odontodes; spinelet short; spine relatively large, adpressed distal tip surpassing last dorsal-fin branched ray origin; anterior margin with small odontodes. Pectoral fin triangular, its origin just posterior to gill opening. Pectoral-fin rays I, 8 
(17), I,9* (3); posterior margin of pectoral-fin spine with 17 to 22 small serrations along its entire length; serrations directed towards pectoral-fin spine tip (Fig. 3d). Pelvic fin oblong, located just below first ventrolateral body plate, and at vertical through first branched dorsal-fin ray. Pelvic-fin rays i,5. Adipose fin roughly triangular, separated from base of last dorsal-fin ray by generally six dorsolateral body plates. Anal fin triangular, located just posterior to $12^{\text {th }}$ ventrolateral body plates, and at vertical through anterior margin of adipose-fin spine. Anal-fin rays ii,6. Caudal-fin rays i,12,i, generally four dorsal and ventral procurrent rays; bilobed; dorsal lobe generally slightly larger than ventral lobe.

Three laterosensory canals on trunk; first ossicle tubular, second ossicle laminar, third canal encased in third dorsolateral body plate. Body plates with minute odontodes scattered over exposed area, a conspicuous line of odontodes confined on posterior margins; dorsolateral body plates 22 (4), 23* (14), 24 (2); ventrolateral body plates $20 *$ (12), 21 (8); dorsolateral body plates along dorsal-fin base $6^{*}(18)$, 7 (2); dorsolateral body plates between adipose and caudal fins $6(7), 7^{*}(12), 8(1)$; preadipose platelets $2(1), 3^{*}(18)$, 4 (1); small platelets covering base of caudal-fin rays; small platelets disposed dorsally and ventrally between junctions of lateral plates on posterior portion of caudal peduncle. Anterior margin of orbit, above lateral ethmoid, covered with small platelets bearing odontodes. Ventral surface of trunk covered by sparse platelets; naked in some specimens.

Color in alcohol. Overall color of body in Fig. 6. Ground color of body light yellow, with top of head and snout dark brown; parieto-supraoccipital entirely dark brown. Maxillary barbel and proximal region of outer mental barbel covered by black chromatophores. Anterior portion of body with irregular black blotches. Posterior margin of first and second dorsolateral body plates blackened. Dorsal portion of body irregularly black pigmented, forming diffuse slender longitudinal black stripe, more conspicuous from dorsal-fin base to adipose-fin origin. Body with two or three conspicuous longitudinal black stripes. Medial portion of dorsal half of dorsolateral body plates with black blotches anteriorly to adipose fin; blotches aligned forming short and narrow longitudinal stripe below dorsal-fin base in some specimens. Midventral half of dorsolateral body plates blackened, forming broad longitudinal stripe along flank. Dorsal half of medial portion of ventrolateral body plates blackened, forming slender longitudinal black stripe along flank; stripe absent or diffuse posteriorly to analfin last branched ray region. Dorsal fin covered by sparse brown chromatophores, more concentrated on its base; upper half of first and second dorsal-fin rays, including membranes, with more concentrated black chromatophores; dorsal-fin spine brownish. Pectoral-fin rays with sparse black chromatophores; pectoral-fin spine brownish. Pelvic fin hyaline. Adipose fin with posterior margin brownish or blackened; adipose-fin spine dorsal half blackened. Caudal fin with scattered brownish chromatophores; black spots arranged in one to four transversal black bars; bars diffuse or absent in some specimens; caudal-fin base blackened; region just posterior to caudal fin base hyaline and with light yellow pigmentation.

Sexual dimorphism. Except for the presence of lanceolate genital papilla in males, which occurs in all Corydoradinae (see Nijssen \& Isbrücker, 1980; Britto, 2003), no other sexually dimorphic feature was observed.

Distribution. The new species is known from its typelocality, a tributary to the rio Aripuanã, Mato Grosso State (Fig. 5).

Ecological notes. The only known specimens of Corydoras pavanelliae were collected among C. brittoi specimens. For notes on its ecology, see Ecological notes of C. brittoi.

Etymology. Corydoras pavanelliae is named in honor of Carla Simone Pavanelli, advisor of the first author and dear friend, for her extensive contributions to the knowledge of the ecology and taxonomy of the Neotropical fishes. A genitive.

Conservation status. The known specimens of Corydoras pavanelliae are relatively numerous and were collected among $C$. brittoi specimens. For this reason, we also suggest that $C$. pavanelliae would be classified as Least Concern (LC) according to the International Union for Conservation of Nature (IUCN) categories and criteria (IUCN Standards and Petitions Subcommittee, 2014).

\section{Discussion}

In general, Corydoradinae species with convergent color pattern can be clearly distinguished from each other by snout morphology (see Alexandrou et al., 2011: 2, fig. 1). Corydoras pavanelliae presents the general morphological features common to lineages ' 6 ' and ' 9 ' sensu Alexandrou et al. (2011), both characterized mainly by (I) the presence of a short mesethmoid; (II) posterior margin of the pectoralfin spine with serrations generally directed towards the tip of the spine; (III) infraorbital 1 generally with poorly to moderately developed ventral laminar expansion; and (IV) infraorbital 2 generally not contacting compound pterotic. Despite both lineages sharing some general external morphology, Alexandrou et al. (2011) and Vera-Alcaraz (2013) found evidence that these two clades do not form a monophyletic group. However, most of Alexandrou et al.'s (2011) phylogenetic inferences are based on molecular characters, which are not yet available for $C$. pavanelliae. Therefore, it is as yet not possible to clearly determine which lineage C. pavanelliae belongs to.

On the other hand, Corydoras brittoi presents the typical intermediate long snout pattern, which is present in most species from the 'lineage 8' sensu Alexandrou et al. (2011). The species from the 'lineage 8', with exception of 
C. difluviatilis Britto \& Castro, 2002 and C. garbei Ihering, 1911, can be distinguished from the other congeners by the presence of dorsal-fin spine with serrations directed towards the origin of the spine. Other features common to species of the lineage 8 are (I) the presence of long mesethmoid; (II) laminar serrations on posterior margins of dorsal- and pectoral-fin spines; (III) infraorbital 1 generally with poorly to moderately developed ventral laminar expansion; and (IV) infraorbital 2 contacting compound pterotic. Despite the fact that $C$. difluviatilis and $C$. garbei are recognized as belonging to lineage 8 according to Alexandrou et al. (2011), they display a morphological pattern much closer to the species of 'lineage 7', which can be characterized by (I) the presence of rounded snout; (II) serrations on dorsaland pectoral-fin spines, when present, poorly developed and directed towards the tip of the spines; (III) ventral laminar expansion of infraorbital 1 very large; and (IV) infraorbital 2 contacting compound pterotic. Therefore, the phylogenetic positions of $C$. difluviatilis and C. garbei, may require further investigation. Notwithstanding these two exceptions, C. brittoi shares the same serration pattern of the dorsal-fin spine observed in all of the species from the lineage 8 sensu Alexandrou et al. (2011).

Twenty-two Corydoras species have previously been described from the rio Madeira drainage: $C$. albolineatus Knaack, 2004, C. bilineatus Knaack, 2002, C. caudimaculatus Rössel, 1961, C. cervinus Rössel, 1962, C. cruziensis Knaack, 2002, C. geryi Nijssen \& Isbrücker, 1983, C. gossei Nijssen, 1972, C. gracilis Nijssen \& Isbrücker, 1976, C. guapore Knaack, 1961, C. haraldschultzi, C. isbrueckeri, C. latus Pearson, 1924, C. mamore Knaack, 2002, C. noelkempffi, C. negro Knaack, 2004, C. paragua Knaack, 2004, C. pinheiroi, C. pygmaeus Knaack, 1966, C. sarareensis Dinkelmeyer, 1995, C. seussi, C. similis Hieronimus, 1991, C. spectabilis, and C. sterbai.

Seven more Corydoras species were recorded from the rio Madeira basin by Britto (2013): C. armatus (Günther, 1868), Corydoras cf. ambiacus Cope, 1872, Corydoras aff. bondi, Corydoras aff. griseus Holly, 1940, Corydoras aff. melanistius Regan, 1912, Corydoras cf. polystictus Regan, 1912 and Corydoras cf. trilineatus. Also, with the recent survey efforts, ten additional species were recorded: Corydoras acutus, Corydoras aeneus (Gill, 1858), Corydoras cf. arcuatus, C. narcissus, C. ourastigma Nijssen 1972, C. splendens (Castelnau, 1855) and four morphotypes that represent possibly new species. A key of the Corydoras species collected until 2011 in the rio Madeira basin (Brazilian territory) and information about them, are available in Britto (2013).

With the two new species described here, a total of 42 species are known from the rio Madeira basin. This represents $24.7 \%$ of all Corydoras diversity. Corydoras brittoi and C. pavanelliae can be distinguished from all of their congeners in the rio Madeira basin, with the exception of $C$. bilineatus, C. pinheiroi and C. pygmaeus, by the presence of two to three (up to three only in some specimens of $C$. pavanelliae) longitudinal black stripes on flanks (vs. a single longitudinal black stripe in C. acutus, Corydoras aff. bondi, Corydoras cf. trilineatus; three to four longitudinal rows of black spots on flanks, which may be coalescent and form stripes in some specimens of $C$. haraldschultzi, C. isbrueckeri, C. noelkempffi, C. spectabilis, C. sterbai; a single black stripe on dorsal portion of flank in C. arcuatus, C. gracilis and C. narcissus; conspicuous stripes absent in the remaining species). Both new species presented herein can be distinguished from $C$. bilineatus and C. pinheiroi by the absence of a black marbled coloration on anterior portion of the body (vs. presence), and from C. pygmaeus by the presence of contact between nuchal plate and posterior process of the parieto-supraoccipital ( $v s$. absence).

Comparative material examined. Corydoras acutus: Peru: Unknown department: MNRJ 3985, 2, 47.1-54.8 mm SL, SanshoCaño. Corydoras adolfoi: Brazil: Amazonas: MZUSP 26641, 1, $32.5 \mathrm{~mm}$ SL, holotype of Corydoras adolfoi Burgess, 1982, tributary to the upper rio Negro. Corydoras ambiacus: Peru: Loreto: MCP 26178, 1, 42.5 mm SL, rio Pacaya; MCP 26209, 10 of 19, 25.0-33.3 mm SL, Caño Yarina. Ucayali: MZUSP 26053, 2 , 41.8-47.2 mm SL, Iamiriacocha. Corydoras approuaguensis: French Guyana: Cayenne: MZUSP 27895-6, 2, 43.0-46.1 mm SL, paratypes of Corydoras approuaguensis Nijssen \& Isbrücker, 1983, rio Approuague. Corydoras araguaiaensis: Brazil: Mato Grosso: MZUSP 87155, 4 of 33, 24.9-46.7 mm SL, 2 c\&s, 27.6$31.8 \mathrm{~mm}$ SL, Corixo da Saudade. Corydoras areio: Brazil: Mato Grosso do Sul: ZUFMS-PIS 1314, 15, 34.4-41.9 mm SL, 2 c\&s, 38.1-38.5 mm SL, Periquito stream. Corydoras armatus: Brazil: Amazonas: MZUSP 49567, 1, $45.3 \mathrm{~mm}$ SL, rio Acre. Corydoras aurofrenatus: Paraguay: Concepción: NRM 23529, 10 of 33, 31.4-45.7 mm SL, Arroyo Laguna Penayo where it crosses the road Concepción-Paso Barreto. Corydoras bifasciatus: Brazil: Pará: MZUSP 38976, 16, paratypes, 23.6-30.0 mm SL, creek at left bank of the rio Cururu. Corydoras blochi: Brazil: Roraima: MZUSP 8580, 3, 31.0-42.6 mm SL, paratypes of Corydoras blochi Nijssen, 1971, Igarapé on Fazenda Canadá, tributary to the rio Uraricoera. Corydoras bondi: Guyana: Barima-Waini: ROM 66202, 7 of 134, 33.8-39.9 mm SL, 3 c\&s of 134, 36.7-38.6 mm SL, Waikerebi Creek. Corydoras brevirostris: Venezuela: Bolívar: LBP 3080, 10, 23.8-27.7 mm SL, 3 c\&s, 25.8-27.9 mm SL, Río Orinoco. Corydoras britskii: Brazil: Mato Grosso do Sul: ZUFMS-PIS 862, 12, 72.0-78.0 mm SL, marginal lagoon to rio Vermelho. Corydoras carlae: Brazil: Paraná: NUP 711, 1, $47.9 \mathrm{~mm} \mathrm{SL}$, rio Tormenta; NUP 4425, 1 c\&s, $45.0 \mathrm{~mm}$ SL, rio Tormenta. Corydoras cervinus: Brazil: Mato Grosso: LBP 10097, 2, 38.9-39.7 mm SL, tributary to rio Guaporé. Corydoras cochui: Brazil: Goiás: MZUSP 89055, 6, 18.7-23.6 mm SL, rio do Peixe II. Tocantins. MZUSP 35838, 4 of 6, 16.1-18.5 mm SL, rio Javaés. Corydoras condiscipulus: French Guyana: Cayenne: MZUSP 38957, 7, 34.1-40.3 mm SL, paratypes of Corydoras condiscipulus Nijssen \& Isbrücker, 1980, Cumuri Creek. Corydoras coppenamensis: Suriname: Saramacca: MZUSP 13995-99, 5, 28.2-34.9 mm SL, paratypes of Corydoras bondi coppenamensis Nijssen, 1970, rio Coppename. Corydoras 
crimmeni: Brazil: Uncertain state: MZUSP 52490, 1, $36.1 \mathrm{~mm}$ SL, holotype of Corydoras crimmeni Grant, 1998, aquarium specimens said to be from near the town of Boa Vista, Roraima, possibly from the rio Branco. Corydoras davidsandsi: Brazil: Amazonas: MZUSP 110066, 4 of 40, 36.0-41.9 mm SL, 2 c\&s of 40, 40.9-42.1 mm SL, rio Inambú. Corydoras difluviatilis: Brazil: São Paulo: MZUSP 75268, 1, 39.8 mm SL, holotype of Corydoras difluviatilis Britto \& Castro, 2002, Paulicéia stream. Corydoras diphyes: Paraguay: Alto Paraná: ANSP 169756, 2, 40.7-43.1 mm SL, drainage ditches north of $\mathrm{km} 250$ (2 km east of Juan E. O'Leary on route 7). Corydoras ehrhardti: Brazil: Paraná: NUP 11255, 15, 36.5-46.8 mm SL, rio São Pedro. Corydoras elegans: Peru: Ucayali: MZUSP 26017, 6, 25.9-28.3 mm SL, Lobococha. Corydoras ephippifer: Brazil: Amapá: MZUSP 31605, 2, 44.9-49.1 mm SL, rio Cupixi. Corydoras eques: Brazil: Amazonas: MCZ 8204, 4 of 12, 37.6-44.4 mm SL, paratypes of Corydoras eques Steindachner, 1876, rio Amazonas at Codajás. Corydoras flaveolus: Brazil: São Paulo: MZUSP 424, 1, $33.4 \mathrm{~mm}$ SL, holotype of Corydoras flaveolus Ihering, 1911, tributaries to the rio Piracicaba. Corydoras fowleri: Peru: Loreto: LBP 12462, 9, 44.3-59.9 mm SL, 1 c\&s, 50.4 mm SL, tributary to the rio Ampiyacu. Corydoras garbei: Brazil: Minas Gerais: MNRJ 18089, 14, 19.2-25.3 mm SL, 2 c\&s, 25.9-27.4 mm SL, Perta-Pé lagoon. Corydoras geoffroy: Suriname: Marowijne: MZUSP 38984, 2, 38.7-45.2 mm SL, paratypes of Corydoras octocirrus Nijssen, 1970, fall in the rio Oelamari. Corydoras gossei: Brazil: Rondônia: MZUSP 38977, 6, 48.4-53.4 mm SL, paratypes of Corydoras gossei Nijssen, 1972, Igarapé do 13, tributary to the rio Mamoré. Corydoras griseus: Guyana: Potaro-Siparuni: MZUSP 108896, 4 of 13, 31.5-36.2 mm SL, 2 c\&s of 13, 30.6-34.5 mm SL, Igarapé tributary to the rio Kuribrong. Corydoras guapore: Brazil: Mato Grosso: ZUFMSPIS 4000, 5, 26.9-33.6 mm SL, 2 c\&s, 28.8-29.2 mm SL, rio Guaporé. Corydoras gryphus: Brazil: Paraná: MNRJ 40770, 1, $32.3 \mathrm{~mm}$ SL, holotype of Corydoras gryphus Tencatt, Britto \& Pavanelli, 2014, rio Paraná (near Ponte da Amizade). NUP 14676, 3 c\&s, 27.7-32.4 mm SL, paratypes of Corydoras gryphus Tencatt, Britto \& Pavanelli, 2014, rio Paraná (near Ponte da Amizade). Corydoras hastatus: Brazil: Mato Grosso: NUP 6862, 116, 13.1-20.7 mm SL, baía Caiçara. Corydoras incolicana: Brazil: Amazonas: MZUSP 45717, 1, $47.6 \mathrm{~mm}$ SL, holotype of Corydoras incolicana Burgess, 1993, rio Içana. Corydoras julii: Brazil: Piauí: NUP 16225, 1, 46.8 mm SL, rio Atalaia. Corydoras kanei: Brazil: Uncertain state: MZUSP 52489, 1, 36.6 mm SL, holotype of Corydoras kanei Grant, 1998, aquarium specimens said to be from near the town of Boa Vista, Roraima, possibly from the rio Branco. Corydoras lacrimostigmata: Brazil: Paraná: MNRJ 40725, 1, $31.8 \mathrm{~mm}$ SL, holotype of Corydoras lacrimostigmata Tencatt, Britto \& Pavanelli, 2014, rio Maria Flora; NUP 14657, 3 c\&s, 30.9-34.5 mm SL paratypes of Corydoras lacrimostigmata Tencatt, Britto \& Pavanelli, 2014, rio Nestor. Corydoras longipinnis: Argentina: Santiago del Estero: AI 221, 1, $59.5 \mathrm{~mm}$ SL, holotype of Corydoras longipinnis Knaack, 2007, río Sali. Tucumán: NUP 14440, 2 c\&s, 29.9-33.4 mm SL, Pampa-Mayo stream. Corydoras lymnades: Brazil: Minas Gerais: MNRJ 15765, 6, 15.8-17.7 mm SL, 2 c\&s, 18.1-18.4 mm SL, rio Peruaçu; MNRJ 40186, 1, 29.7 mm SL, holotype of Corydoras lymnades Tencatt, Vera-Alcaraz, Britto \& Pavanelli, 2013, rio Guarda-Mor. Corydoras maculifer: Brazil: Tocantins: NUP 8970, 2, 42.0-46.0 mm SL, ribeirão Xambioazinho. Corydoras melanistius: Guyana: Unknown region: BMNH 1864.1.21.86, 1, $35.0 \mathrm{~mm}$ SL, lectotype of Corydoras melanistius Regan, 1912, designated by Nijssen \& Isbrücker, 1967, rio Essequibo. Corydoras melini: Brazil: Amazonas: MZUSP 81163, 2, 37.0-45.0 mm SL, rio Tiquié. Corydoras multimaculatus: Brazil: Minas Gerais: MCP 29025, 2, 20.1-25.4 mm SL, rio Peruaçu. Corydoras napoensis: Peru: Loreto: MZUSP 26341, 1, $27.8 \mathrm{~mm}$ SL, paratype of Corydoras napoensis Nijssen \& Isbrücker, 1986, Moronacocha. Corydoras nattereri: Brazil: São Paulo: MZUSP 110255, 4 of 31, 32.0-32.8 mm SL, 2 c\&s of 31, 32.3-34.4 mm SL, rio Paraitinga. Corydoras paleatus: Uruguay: Canelones: NRM 54230, 1, 53.5 mm SL, Sarandí stream. Corydoras panda: Peru: Huánuco: ROM 55815, 6, 26.5-39.7 mm SL, unknown stream somewhere above Panguana in Llullapichis drainage. Corydoras pantanalensis: Brazil: Mato Grosso: NUP 10188, 1 c\&s, 46.4 mm SL, Baía Sinhá Mariana. Mato Grosso do Sul. NUP 12593, 21, 38.7-51.2 $\mathrm{mm} \mathrm{SL}$, tributary to the rio Miranda. Corydoras parallelus: Brazil: Amazonas: MZUSP 45716, 1, 47.4 mm SL, holotype of Corydoras parallelus Burgess, 1993, rio Içana. Corydoras pinheiroi: Brazil: Rondônia: MZUSP 48099, 1, $54.3 \mathrm{~mm}$ SL, holotype of Corydoras pinheiroi Dinkelmeyer, 1995, stream tributary to the rio Ribeiro, at Guajará-Mirim. Corydoras potaroensis: Guyana: PotaroSiparuni: ROM 61526, 3 of 15, 35.0-44.8 mm SL, 2 c\&s of 15, 32.6-35.1 mm SL, rio Potaro. Corydoras pygmaeus: Peru: Loreto: MZUSP 26344, 4, 13.5-20.0 mm SL, Moronacocha. Corydoras reticulatus: Peru: Ucayali: MZUSP 28752, 3, 37.3-45.1 mm SL, Iamiriacocha masisea. Corydoras robineae: Brazil: Amazonas: MZUSP 27175, 1, $33.7 \mathrm{~mm}$ SL, holotype of Corydoras robineae Burgess, 1983, rio Aiuana. Corydoras sarareensis: Brazil: Mato Grosso: MZUSP 48100, 1, 40.9 mm SL, holotype of Corydoras sarareensis Dinkelmeyer, 1995, rio Sararé. Corydoras seussi: Brazil: Rondônia: MZUSP 49323, 10, 44.3-54.0 mm SL, paratypes of Corydoras seussi Dinkelmeyer, 1996, small stream tributary to the rio Pacas-Novos (= Pacaás Novos), near GuajaráMirim. Corydoras similis: Brazil: Acre: LBP 10648, 7, 21.4-34.3 mm SL, rio Iquiri. Corydoras splendens: Brazil: Goiás: NUP 12990, 1, $43.7 \mathrm{~mm} \mathrm{SL}$, tributary to the rio Araguaia. Mato Grosso. NUP 10195, 1 c\&s, 54.6 mm SL, Pai Caetano lake. Corydoras stenocephalus: Brazil: Amazonas: MNRJ 3625, 3, 31.2-62.3 mm SL, rio Javari. Corydoras sterbai: Brazil: Mato Grosso: MZUSP 94998, 1, 39.9 mm SL, rio Guaporé. Corydoras treitlii: Brazil: Maranhão: NUP 16224, 3, 21.5-45.6 mm SL, rio Medonho. Corydoras trilineatus: Brazil: Acre: MZUSP 30857, 3 of 25, 40.9-44.1 mm SL, 2 c\&s of 25, 44.2-43.8 mm SL, rio Tarauacá. Corydoras tukano: Brazil: Amazonas: MZUSP 82100, $40.9 \mathrm{~mm}$ SL, holotype of Corydoras tukano Britto \& Lima, 2003, rio Tiquié. Corydoras xinguensis: Brazil: Mato Grosso: MZUSP 38987, 1, 34.5 mm SL, paratype of Corydoras xinguensis Nijssen, 1971, Igarapé upstream Porori village. Corydoras zygatus: Brazil: Acre: MZUSP 30858, 4 of 15, 41.7-47.3 mm SL, rio Tarauacá. 


\section{Acknowledgements}

The Núcleo de Pesquisas em Limnologia, Ictiologia e Aquicultura (Nupélia) of the Universidade Estadual de Maringá and the Laboratório de Zoologia da Universidade Federal de Mato Grosso do Sul provided logistical support. We are grateful to Bruno Barros (Naturae), Diogo Hungria (GIA), Ariana Ribeiro, Fabíola Vieira (UFRO), and Cintia Oliveira (FSL) for help during the fieldwork. To Carolina Doria and Mariluce Messias (UNIR) for the donation of the specimens used in the description of both new species. This work is part of the project "Monitoramento e Conservação da Ictiofauna do rio Madeira", a partnership involving the Universidade Federal de Rondônia, Instituto de Estudos e Pesquisas do Agronegócio e Organizações Sustentáveis and Santo Antônio Energia (2009-2012). The authors are grateful to Carlos Lucena (MCP), Cláudio Oliveira (LBP), Mário de Pinna, Aléssio Datovo and Osvaldo Oyakawa (MZUSP), Mariluce Messias and Ângela Araujo (UFRO) and Otávio Froehlich (in memoriam) (ZUFMS-PIS) for hosting museum visits, curatorial assistance and loaning of material. We also thank Hernán López-Fernández, Don Stacey and Erling Holm (ROM), Jorge Casciotta and Adriana Almirón (AI), Juan Mirande (Fundación Miguel Lillo), Marcelo Britto (MNRJ) and Sven Kullander (NRM) for the loaning and/or donation of several specimens analyzed in this paper. To Andressa Oliveira, Francisco Severo-Neto and Thomaz Sinani (ZUFMS-PIS), Carlos Lucena and Héctor Vera-Alcaraz (MCP), Cláudio Oliveira, Ricardo Britzke, Fábio Roxo, Bruno Melo and Gabriel Silva (LBP), Osvaldo Oyakawa and Túlio Teixeira (MZUSP) for gently welcome LFCT during museum visits. To Marcelo Britto (MNRJ) for kindly share his knowledge about Corydoradinae with LFCT, and for sending several photographs of types hosted in BMNH. To Robert McLure for the pleasant late-night talks on Corydoras and for kindly reviewing the English language of this paper. To William Crampton and four anonymous reviewers for the valuable suggestions on this manuscript. To Celso Ikedo for taking the photos used in figures 1 and 6 . To Fernando Paiva and Lucas Blanco by permitting the use and by the assistance in the image capture laboratory of the Universidade Federal de Mato Grosso do Sul. The Conselho Nacional de Desenvolvimento Científico e Tecnológico $(\mathrm{CNPq})$ provided fellowships to LFCT (process \#141061/2014-6) and the Fundação de Amparo à Pesquisa do Estado de São Paulo (FAPESP) provided grants to WMO (process \#2013/22473-8).

\section{References}

Alexandrou, M. A., C. Oliveira, M. Maillard, R. A. R. McGill, J. Newton, S. Creer \& M. I. Taylor. 2011. Competition and phylogeny determine community structure in Müllerian comimics. Nature, 469: 84-89.

Aquino, A. E. \& S. A. Schaefer. 2002. The temporal region of the cranium of loricarioid catfishes (Teleostei: Siluriformes): morphological diversity and phylogenetic significance. Zoologischer Anzeiger, 241: 223-244.
Arratia, G. \& M. Gayet. 1995. Sensory canals and related bones of Tertiary siluriform crania from Bolivia and North America and comparison with recent forms. Journal of Vertebrate Paleontology, 15: 482-505.

Axenrot, T. E. \& S. O. Kullander. 2003. Corydoras diphyes (Siluriformes: Callichthyidae) and Otocinclus mimulus (Siluriformes: Loricariidae), two new species of catfishes from Paraguay, a case of mimetic association. Ichthyological Exploration of Freshwaters, 14: 249-272.

Britto, M. R. 2003. Phylogeny of the subfamily Corydoradinae Hoedeman, 1952 (Siluriformes: Callichthyidae), with a definition of its genera. Proceedings of the Academy of Natural Sciences of Philadelphia, 153: 119-154.

Britto, M. R. 2013. Callichthyidae. Pp. 180-195. In: Queiroz, L. J., G. Torrente-Vilara, W. M. Ohara, T. H. S. Pires, J. Zuanon \& C. R. C. Doria. (Org.). Peixes do rio Madeira, 1 ed. São Paulo, Dialeto Latin American Documentary.

Britto, M. R. \& R. M. C. Castro. 2002. New corydoradine catfish (Siluriformes: Callichthyidae) from the upper Paraná and São Francisco: the sister group of Brochis and most of Corydoras species. Copeia, 2002: 1006-1015.

Britto, M. R. \& F. C. T. Lima. 2003. Corydoras tukano, a new species of corydoradine catfish from the rio Tiquié, upper rio Negro basin, Brazil (Ostariophysi: Siluriformes: Callichthyidae). Neotropical Ichthyology, 1: 83-91.

Britto, M. R., W. B. Wosiacki \& L. F. A. Montag. 2009. A new species of Corydoradinae catfish (Ostariophysi: Siluriformes: Callichthyidae) from Rio Solimões Basin, Brazil. Copeia, 2009(4): 684-689.

Burgess, W. E. 1983. Corydoras robineae, a new species of callichthyid catfish from Brazil. Tropical Fish Hobbyist, 31: 42-43.

Burgess, W. E. 1993. Three new species of catfishes of the genus Corydoras (Callichthyidae: Siluriformes). Tropical Fish Hobbyist, 41: 152-158.

Castelnau, F. 1855. Poissons. In: Animaux nouveaux ou rares recueillis pendant l'expédition dans les parties centrales de l'Amérique du Sud, de Rio de Janeiro à Lima, et de Lima au Para; exécutée par ordre du gouvernement Français pendant les années 1843 à 1847. Paris, Chez P. Bertrand, 112p.

Castro, D. M. 1986. Corydoras gomezi a new species from Colombia (Pisces, Siluriformes, Callichthyidae). Boletin Ecotrópica, 15: 33-38.

Cope, E. D. 1872. On the fishes of the Ambyiacu River. Proceedings of the Academy of Natural Sciences of Philadelphia, 23: 250-294.

Dinkelmeyer, J. 1995. Zwei neue Arten von Panzerwelsen der Gattung Corydoras Lacépède, 1803 aus Brasilien (Pisces, Siluriformes, Callichthyidae). Aquaristik aktuell, 1995: 60-61.

Dinkelmeyer, J. 1996. Corydoras seussi n. sp., ein neuer Panzerwels aus Brasilien (Pisces, Siluriformes, Callichthyidae). Aquaristik aktuell, 1996: 25-26.

Ellis, M. D. 1913. The plated nematognaths. Annals of the Carnegie Museum, 8: 384-413.

Elwin, M. G. 1939. Corydoras arcuatus sp. n., an Amazonian catfish. Annals and Magazine of Natural History, 3: 126128.

Eschmeyer, W. N. (Ed.). 2015. Catalog of fishes: genera, species, references. San Francisco, CA, California Academy of Sciences. 3v., ill. Available from http://research.calacademy. org/ichthyology/catalog/fishcatmain.asp/. (3 Jun 2015). 
Geisler, R. 1969. Corydoras baderi, ein neuer Panzerwels, und sein Lebensraum im Grenzgebiet Brasilien--Surinam (Pisces, Teleostei, Callichthyidae). Senckenbergiana Biologica, 50: 353-357.

Gill, T. N. 1858. Synopsis of the fresh water fishes of the western portion of the island of Trinidad. W. I. Annals of the Lyceum of Natural History of New York, 6: 363-430.

Gosline, W. A. 1940. A revision of the Neotropical catfishes of the family Callichthyidae. Stanford Ichthyological Bulletin, 2: $1-36$.

Günther, A. 1868. Diagnoses of some new freshwater fishes from Surinam and Brazil, in the collection of the British Museum. Annals and Magazine of Natural History, 1: 475-481.

Hieronimus, H. 1991. Corydoras similis spec. nov., ein neuer Panzerwels aus Brasilien (Pisces: Siluriformes: Callichthyidae). Zeitschrift für Fischkunde, 1: 39-46.

Hoedeman, J. J. 1965. Elseviers pocketboek voor de aquariumliefhebber. Amsterdam, Elservier, $176 \mathrm{p}$. (Elsevierpocket, no. 108).

Holly, M. 1940. Vier noch nicht beschriebene Corydoras Arten. Anzeiger der Akademie der Wissenschaften in Wien, 77: 107112.

Huysentruyt, F. \& D. Adriaens. 2005. Descriptive osteology of Corydoras aeneus (Siluriformes: Callichthyidae). Cybium, 29: 261-273.

Ihering R. 1911. Algumas espécies novas de peixes d'água doce (Nematognatha) (Corydoras, Plecostomus, Hemipsilichthys). Revista do Museu Paulista, 8: 380-404.

International Union for Conservation of Nature (IUCN). Standards and Petitions Subcommittee. 2014. Guidelines for using the IUCN Red List Categories and Criteria. Version 11. Prepared by the Standards and Petitions Subcommittee. Available from http://www.iucnredlist.org/documents/RedListGuidelines.pdf. (14 Jul 2015).

Isbrücker, I. J. H. \& H. Nijssen. 1973. Two new species of the callichthyid catfish genus Corydoras from Brazil (Pisces, Siluriformes, Callichthyidae). Beaufortia, 21: 1-7.

Jenyns, L. 1842. Fish. In: Darwin C. R (Ed.). The Zoology of the voyage of H. M. S. Beagle, under the command of Captain Fitzroy, R. N., during the years 1832 to 1836 . London, Smith, Elder, and Co., Pat 4 (v. 4).

Knaack, J. 1961. Ein neuer Panzerwels aus Brasilien (Corydoras guapore) (Pisces, Teleostei, Callichthyidae). Sitzungsberichte der Gesellschaft Naturforschender Freunde zu Berlin (n. f.), 1: 135-138.

Knaack, J. 1962. Zwei neue Panzerwelse, Corydoras haraldschultzi und Corydoras sterbai (Pisces, Teleostei, Callichthyidae). Senckenbergiana Biologica, 43: 129-135.

Knaack, J. 1966. Ein Zwergpanzerwels aus brasilien- Corydoras pygmaeus.Die Aquarien und Terrarien-Zeitschrift, 19: 168-169.

Knaack, J. 2000. Eine weitere neue Art der Gattung Corydoras Lacépède, 1803 aus dem Mato Grosso (Pisces, Siluriformes, Callichthyidae). VDA-aktuell, 2000: 74-79.

Knaack, J. 2002. Ein neuer Panzerwels aus Bolivien: Corydoras bilineatus n. sp. (Pisces, Siluriformes, Callichthyidae). Aquaristik aktuell, 1: 50-56.

Knaack, J. 2003. Ein weiterer neuer Panzerwels aus Bolivien: Corydoras cruziensis n. sp. (Pisces, Siluriformes, Callichthyidae). VDA-aktuell, 2003: 60-69.

Knaack, J. 2003. Ein weiterer neuer Panzerwels aus Bolivien: Corydoras mamoren. sp. (Pisces, Siluriformes, Callichthyidae). VDA aktuell, 10: 16-24.
Knaack, J. 2004. Beschreibung von sechs neuen Arten der Gattung Corydoras La Cépède, 1803 (Teleostei: Siluriformes: Callichthyidae). Zoologische Abhandlungen (Dresden) Staatliches Museum für Tierkunde in Dresden, 54: 55-105.

Knaack J. 2007. Beitraege zur Kenntnis der Callichthyidae (Teleostei: Siluriformes). III. Corydoras longipinnis sp. n. ein neuer Panzerwels aus dem río Dulce in Argentinien (Teleostei: Siluriformes: Callichthyidae). Vertebrate Zoology, 57: 35-55.

Lacépède, B. G. E. 1803. Histoire naturelle des poissons. Paris, Chez Plassan, t. 5, 803p.

Lönnberg, E. \& H. Rendahl. 1930. Eine neue Art der Gattung Corydoras. Arkiv för Zoologi, 22: 1-6.

Lundberg, J. G. 1970. The evolutionary history of North American catfishes, family Ictaluridae. Unpubl. Ph. D. Dissertation, University of Michigan, Ann Arbor, Michigan, 524p.

Morris, P. J., H. M. Yager \& M. H. Sabaj Pérez. (Ed.). 2006. ACSImagebase: a digital archive of catfish images compiled by participants in the All Catfish Species Inventory. Available from http://acsi.acnatsci.org/base/ (3 Jun 2015).

Myers, G. S. 1927. Descriptions of new South American freshwater fishes collected by Dr. Carl Ternetz. Bulletin of the Museum of Comparative Zoology, 68: 107-135.

Myers, G. S. 1933. New importations. Leopard Corydoras. The Aquarium, Philadelphia, 2: 188-189.

Myers, G. S. \& S. H. Weitzman. 1960. Two new fishes collected by General Thomas D. White in eastern Colombia. Stanford Ichthyological Bulletin, 7: 98-109.

Nijssen, H. 1970. Revision of the Surinam catfishes of the genus Corydoras Lacépède, 1803 (Pisces, Siluriformes, Callichthyidae). Beaufortia, 18: 1-75.

Nijssen, H. 1972. Records of the catfish genus Corydoras from Brazil and French Guiana with descriptions of eight new species (Pisces, Siluriformes, Callichthyidae). Netherlands Journal of Zoology, 21: 412-433.

Nijssen, H. \& I. J. H. Isbrücker. 1967. Notes on the Guiana species of Corydoras Lacépède, 1803, with descriptions of seven new species and designation of a neotype for Corydoras punctatus (Bloch, 1794) (Pisces, Cypriniformes, Callichthyidae). Zoologische Mededelingen, 42: 21-50.

Nijssen, H. \& I. J. H. Isbrücker. 1976. A new callichthyid catfish, Corydoras gracilis, from Brazil. Tropical Fish Hobbyist, 25: 90-98.

Nijssen, H. \& I. J. H. Isbrücker. 1976. Corydoras ornatus, a new species of callichthyid catfish from the Rio Tapajós drainage, Brazil (Pisces, Siluriformes, Callichthyidae). Bulletin Zoölogisch Museum, Universiteit van Amsterdam, 5: 125-129.

Nijssen, H. \& I. J. H. Isbrücker. 1980. A review of the genus Corydoras Lacépède, 1803 (Pisces, Siluriformes, Callichthyidae). Bijdragentot de Dierkunde, 50: 190-220.

Nijssen, H. \& I. J. H. Isbrücker. 1980. Three new Corydoras species from French Guiana and Brazil (Pisces, Siluriformes, Callichthyidae). Netherlands Journal of Zoology, 30: 494-503.

Nijssen, H. \& I. J. H. Isbrücker. 1980. On the identity of Corydoras nattereri Steindachner 1877 with the description of a new species Corydoras prionotos (Pisces, Siluriformes, Callichthyidae). Beaufortia, 30: 1-9.

Nijssen, H. \& I. J. H. Isbrücker. 1983. Review of the genus Corydoras from Colombia, with descriptions of two new species (Pisces, Siluriformes, Callichthyidae). Beaufortia, 33 : $53-71$. 
Nijssen, H. \& I. J. H. Isbrücker. 1983. Sept espèces nouvelles de poissons-chats cuirassés du genre Corydoras Lacepède, 1803, de Guyane française, de Bolivie, d'Argentine, du Surinam et du Brésil (Pisces, Siluriformes, Callichthyidae). Revue Française d'Aquariologie Herpétologie, 10: 73-82.

Pearson, N. E. 1924. The fishes of the eastern slope of the Andes. I. The fishes of the Rio Beni basin, Bolivia, collected by the Mulford Expedition. Indiana University Studies, 11: 1-83.

Regan, C. T. 1912. A revision of the South-American siluroid fishes of the genus Corydoras, with a list of the specimens in the British Museum (Natural History). Annals and Magazine of Natural History, 10: 209-220.

Reis, R. E. 1997. Revision of the Neotropical catfish genus Hoplosternum (Ostariophysi: Siluriformes: Callichthyidae), with the description of two new genera and three new species. Ichthyological Exploration of Freshwaters, 7: 299-326.

Reis, R. E. 1998. Anatomy and phylogenetic analysis of the neotropical callichthyid catfishes (Ostariophysi, Siluriformes). Zoological Journal of the Linnean Society, 124: $105-168$

Reis, R. E. 2003. Family Callichthyidae (Armored catfishes). Pp. 291-309. In: Reis, R. E., S. O. Kullander \& C. J. Ferraris, Jr. (Orgs.). Check list of the freshwater fishes of South and Central America. Porto Alegre, Edipucrs.

Rössel, F. 1961. Corydoras caudimaculatus ein neuer Panzerwels aus Brasilien. (Pisces, Teleostei, Callichthyidae). Senckenbergiana Biologica, 42: 49-50.

Rössel, F. 1962. Corydoras axelrodi, ein neuer Panzerwels aus Columbien (Pisces, Teleostei, Callichthyidae). Senckenbergiana Biologica, 43: 31-33.

Rössel, F. 1962. Corydoras cervinus, ein neuer Panzerwels aus Brasilien (Pisces, Teleostei, Callichthyidae). Senckenbergiana Biologica, 43: 31-33.

Rössel, F. 1963. Neue und seltene Corydoras-Arten aus Brasilien (Pisces, Teleostei, Callichthyidae). Senckenbergiana Biologica, 44: 359-363.

Schaefer, S. A. 1988. Homology and evolution of the opercular series in the loricarioid catfishes (Pisces: Siluroidei). Journal of Zoology, 214: 81-93.

Schaefer, S. A. \& A. E. Aquino. 2000. Postotic laterosensory canal and pterotic branch homology in catfishes. Journal of Morphology, 246:212-227.
Steindachner, F. 1876. Ichthyologische Beiträge (V). Sitzungsberichte der Kaiserlichen Akademie der Wissenschaften mathematisch-naturwissenschaftliche Klasse, 74: 49-240.

Steindachner, F. 1906. Das w. M. Hefrat F. Steindachner berichtet über zwei neue Corydoras-Arten aus dem Parnahyba- und Parahum-Flusse im Staate Piauhy welche von ihm wahrend der zoologischen Expedition der Kaiserl. Anzeiger der Kaiserlichen Akademie der Wissenschaften, MatematischNaturwissenschaftlichen Klasse, 43: 478-480.

Steindachner, F. 1910. Über eine neue Loricaria-Art aus dem Flussgebiete des Jaraguá und der Ribeira im Staate S. Paulo und Sa. Catharina über eine mit ancistrus aculeatus (Perugia). Anzeiger der Akademie der Wissenschaften in Wien, 47: $57-$ 62.

Taylor, W. R. \& G. C. Van Dyke. 1985. Revised procedures for staining and clearing small fishes and other vertebrates for bone and cartilage study. Cybium, 9: 107-119.

Tencatt L. F. C., H. S. Vera-Alcaraz, M. R. Britto \& C. S. Pavanelli. 2013. A new Corydoras Lacépède, 1803 (Siluriformes: Callichthyidae) from the rio São Francisco basin, Brazil. Neotropical Ichthyology, 11: 257-264.

Tencatt, L. F. C. \& C. S. Pavanelli. 2015. Redescription of Corydoras guapore Knaack, 1961 (Siluriformes: Callichthyidae), a midwater Corydoradinae species from the rio Guaporé basin. Neotropical Ichthyology, 13: 287-296.

Vera-Alcaraz, H. S. 2013. Relações filogenéticas das espécies da família Callichthyidae (Ostariophysi, Siluriformes). Unpublished Ph.D. Dissertation, Pontifícia Universidade Católica do Rio Grande do Sul, Porto Alegre, 362p.

Weitzman, S. H. 1960. Figures and description of four South American catfishes of the genus Corydoras, including two new species. Stanford Ichthyological Bulletin, 7: 140-154.

Weitzman, S. H. \& H. Nijssen. 1970. Four new species and one new subspecies of the catfish genus Corydoras from Ecuador, Colombia and Brazil (Pisces, Siluriformes, Callichthyidae). Beaufortia, 18: 119-132. 